\title{
Validation of the Mizāj of Heart by Determining The Ash Value of Vital Organs of Three Species
}

\author{
Khaiser RABEE ${ }^{1}$, Mohd ZULKIFLE ${ }^{1}$, Shariq SHAMSI ${ }^{2}$, Wasim AHMAD ${ }^{1}$, Tariq NADEEM ${ }^{1}$, Abu BAKAR ${ }^{1}$
}

${ }^{1}$ Department of Kulliyat (Basic Science), National Institute of Unani Medicine, Bangalore, India.

${ }^{2}$ Department of Saidla (Pharmacy), National Institute of Unani Medicine, Bangalore, India.

\section{ABSTRACT}

This study aimed to determine the cause of Yäbis attribution in the heart by estimating the ash value of three vital organs, such as heart, brain, and liver, of three species, chicken, goat, and buffalo. Creatures are composed of Arkān Arba 'a in varied proportions, qualitatively and quantitatively most suitable for accomplishing their functions. Philosophers have described the structural and functional variabilities of species in terms of the Mizäj, which relates to its possible dominant Rukn. The Mizāj of human beings is described as the reflection of the Mizāj of their heart and the organs connected to it. The Mizāj of heart is attributed as Hārrt-Yābis.

Twenty-seven samples of vital organs of three species, each obtained from market, were subjected to total ash value determination. The procedure was followed in accordance with the International Standard, ISO 936:1998(E).

The mean ash value of the chicken's heart, brain, and liver was $5.18 \%, 7.62 \%$, and $6.56 \%$, respectively. The mean ash value of the goat's heart, brain, and liver was $2.53 \%, 11.18 \%$ and $4.24 \%$, respectively. The mean ash value in the buffalo's heart, brain, and liver was $5.32 \%, 8.74 \%$, and $6.56 \%$, respectively.

Interpretation and Conclusion: Yubussat is required for hardness, stiffness, and durability to stay active and dynamic. Compared with the brain and liver, the heart's rigid nature, consistent action, and resemblance with the coniferous shape of Rukn Nār indicates the presence of Yubüsat Näriyya. In this study, the least mean total ash value of the heart among all the three species implies the least presence of Ajzä' Ardìya, thus validating the presence of Yubüsat Näriyya in it. Therefore, the heart's structure and function are in accordance with its Harārat and Yubūsat Nāriyya.

Key words: Vital organs; heart; Yubüsat; Yubūsat Nāriyya; structure; function

\section{INTRODUCTION}

In Unani medicine, the Mizāj of an individual is nothing but a mere reflection of the Mizāj of heart and the organs connected to it (1). Moreover, the Mizāj of an individual organ is more important than that of the whole body (2). The Mizàj of the heart is attributed as Ḥārr-Yābis (hot-dry) (3-6).

Ibn Sīnā (980-1037 AD) states that the interaction of Arkān (Nār, Hawā', Mā’ and Arḍ) with each other occurs in different proportions. When the mixture is in the right proportion, a substance is brought into existence physically, while any alteration to it causes that matter to get Fāsid (decomposed). The various orders of Mawālīd Thalatha depend on the intermixing of Arkān in desired proportion (3). 
Similarly, Zakria Razi (865-925 AD) believed that Mawālīd Thalatha (trimatters) disintegrates into Arkān on ignition. Rukn Nār, Rukn Hawā', and Rukn Mā’ being Lațịf (volatile) in nature turn into fumes, while Rukn Arḍ being Kathîf (non-volatile) remains as ash on incineration (7).

Philosophers believed that every species inherits a Mizāj, which is entirely the most appropriate and best adapted for the performance of its functions and passive states. In the case of human beings, they inherit the most befitting Mizāj possible of all in this world, as well as faculties corresponding to all the active and passive states of human. Each organ has also received the proper Mizāj requisite for its function. Some are made hotter with Rukn Nār or Rukn Hawā', some are made colder with Rukn Mā' or Rukn Arḍ, some are made moist with Rukn Mā' or Rukn Hawā', and others are comparatively dry with Rukn Nār or Rukn Arḍ in congruence to their natural needs. Thus, the Mizàj of organs influence the Mizāj of an individual as a whole (2-6).

Though philosophers have described the Mizāj of various organs, they have not explained the parameters of its quantification. They have attributed the Mizāj with respect to its obvious structure and function and in relation to its possible dominant Rukn. This attribution was solely based on logic and philosophy. Today, the interpretation and explanation of philosophy on the attribution of Mizāj is complex and obscure. So, the need was felt to have some analytical means by which subjective realities can be understood in terms of objective paradigm.

In this study, the focus was to determine the cause of Yubüsat in the heart, which could be due to the dominance of either Rukn Nār or Rukn Arḍ. So, the quantification of Rukn Ardị, in terms of the ash value estimation, as a determinant of Yubūsat in three vital organs, namely the heart, brain, and liver, of three species, chicken, goat, and buffalo, was carried out.

\section{MATERIAL AND METHODS}

Fresh vital organs (heart, brain, and liver) of three species, chicken, goat, and buffalo, of either sex were taken from a poultry farm and some butcher shops of Bangalore for this study.
The ash value was determined in accordance with the procedure established by the International Standard for determining the total ash in meat and meat products, including poultry with reference no. 'ISO 936: 1998(E)' (8).

\section{Procedure}

The aforementioned fresh vital organs of the three species were washed well and minced (mincer fitted with a plate with apertures not exceeding $4.0 \mathrm{~mm}$ in diameter was used for homogenizing the organs). The samples of each organ were first spread in the Petri dishes and placed in the drying oven at $105^{\circ} \mathrm{C} \pm 5^{\circ} \mathrm{C}$ for 5 hours. Thereafter, the dried test samples were transferred to crucibles (flat-bottomed silica crucibles with inclined walls of height exceeding $25 \mathrm{~mm}$ ) and placed in the muffle furnace at $550^{\circ} \mathrm{C} \pm 25^{\circ} \mathrm{C}$ for 4 hours. After complete incineration, the muffle furnace was allowed to cool down and the ash samples were weighed.

The total ash content 'wa ' of the test samples was calculated using the following formula:

$\mathrm{w}_{\mathrm{a}}=\left(\mathrm{m}_{2}-\mathrm{m}_{0}\right) /\left(\mathrm{m}_{1}-\mathrm{m}_{0}\right) \times 100 \%$

where $m_{0}$ is the mass of the empty crucible in grams, $m_{1}$ is the mass of the crucible with sample before incineration in grams, and $m_{2}$ is the mass of the crucible with ash after incineration in grams.

The same procedure was repeated thrice to calculate the mean percentage of mass of ashes for the hearts, brains, and livers of the three species. Attempts were made to keep the age and weight of the three species quite close. In this way, altogether 27 vital organs were obtained and subjected to analysis.

\section{RESULTS}

The mean percentage ash values of the vital organs in all the three species were calculated. The mean ash value of the chicken's heart, brain, and liver was found to be $5.18 \%, 7.62 \%$, and $6.56 \%$, respectively (Table 1). The mean ash value of the goat's heart, brain, and liver was found to be $2.53 \%, 11.18 \%$, and $4.24 \%$ (Table 1). The mean ash value of the buffalo's heart, brain, and liver was found to be $5.32 \%, 8.74 \%$, and $6.56 \%$, 

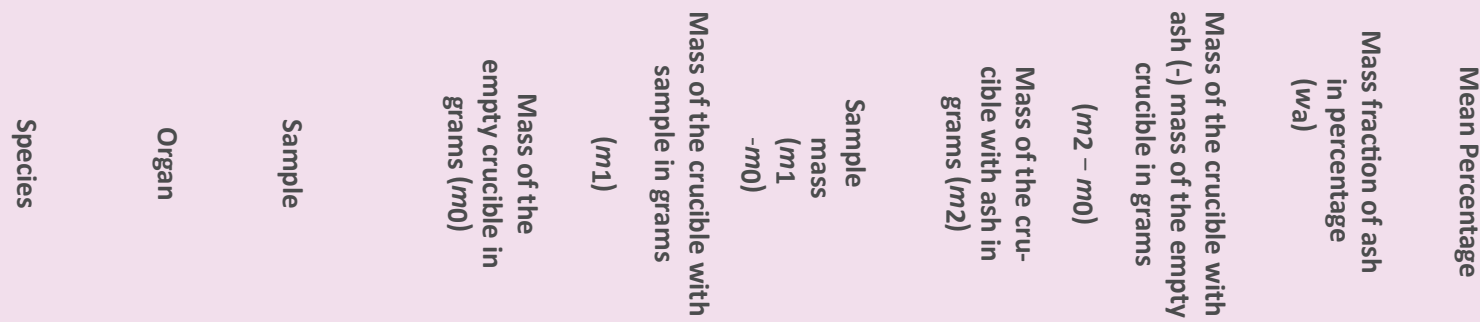

\begin{tabular}{|c|c|c|c|c|c|c|c|c|c|}
\hline \multirow{9}{*}{ 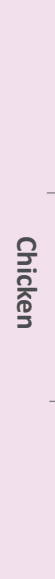 } & \multirow{3}{*}{$\begin{array}{l}\text { I } \\
\text { D } \\
\stackrel{2}{7}\end{array}$} & Sample-1 & 22.587 & 23.603 & 1.016 & 22.643 & 0.056 & 5.511 & \multirow{3}{*}{5.18} \\
\hline & & Sample-2 & 25.257 & 26.270 & 1.013 & 25.310 & 0.053 & 5.231 & \\
\hline & & Sample-3 & 23.738 & 24.743 & 1.005 & 23.787 & 0.049 & 4.800 & \\
\hline & \multirow{3}{*}{$\begin{array}{l}\frac{\text { U్ }}{\mathrm{J}} \\
\frac{1}{3} \text {. }\end{array}$} & Sample-1 & 22.583 & 23.085 & 0.502 & 22.620 & 0.037 & 7.370 & \multirow{3}{*}{7.62} \\
\hline & & Sample-2 & 23.807 & 24.313 & 0.506 & 23.846 & 0.039 & 7.707 & \\
\hline & & Sample-3 & 23.738 & 24.239 & 0.501 & 23.777 & 0.039 & 7.784 & \\
\hline & \multirow{3}{*}{ 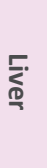 } & Sample-1 & 22.047 & 26.060 & 4.013 & 22.306 & 0.259 & 6.454 & \multirow{3}{*}{6.56} \\
\hline & & Sample-2 & 23.804 & 27.816 & 4.012 & 24.043 & 0.239 & 5.957 & \\
\hline & & Sample-3 & 23.153 & 27.170 & 4.017 & 23.445 & 0.292 & 7.269 & \\
\hline \multirow{9}{*}{$\stackrel{\text { ̊ి }}{\stackrel{\sim}{\sim}}$} & \multirow{3}{*}{$\begin{array}{l}\frac{T}{D} \\
\stackrel{D}{7} \\
\stackrel{2}{7}\end{array}$} & Sample-1 & 22.047 & 26.067 & 4.014 & 22.150 & 0.103 & 2.566 & \multirow{3}{*}{2.53} \\
\hline & & Sample-2 & 23.737 & 27.743 & 4.006 & 23.829 & 0.092 & 2.297 & \\
\hline & & Sample-3 & 23.804 & 27.823 & 4.019 & 23.913 & 0.109 & 2.712 & \\
\hline & \multirow{3}{*}{$\begin{array}{l}\frac{\text { D. }}{\mathrm{J}} \\
\frac{\mathrm{J}}{5}\end{array}$} & Sample-1 & 22.574 & 26.576 & 4.002 & 22.998 & 0.424 & 10.595 & \multirow{3}{*}{11.18} \\
\hline & & Sample-2 & 25.247 & 29.250 & 4.003 & 25.711 & 0.464 & 11.591 & \\
\hline & & Sample-3 & 22.048 & 26.052 & 4.004 & 22.502 & 0.454 & 11.339 & \\
\hline & \multirow{3}{*}{ 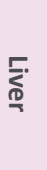 } & Sample-1 & 25.251 & 29.266 & 4.015 & 25.388 & 0.137 & 3.412 & \multirow{3}{*}{4.24} \\
\hline & & Sample-2 & 23.147 & 27.157 & 4.010 & 23.314 & 0.167 & 4.165 & \\
\hline & & Sample-3 & 22.583 & 26.598 & 4.015 & 22.789 & 0.206 & 5.131 & \\
\hline \multirow{9}{*}{$\begin{array}{l}\text { 罢 } \\
\stackrel{\overrightarrow{9}}{0}\end{array}$} & \multirow{3}{*}{$\begin{array}{l}\frac{T}{D} \\
\stackrel{2}{7}\end{array}$} & Sample-1 & 22.054 & 26.062 & 4.008 & 22.280 & 0.226 & 5.639 & \multirow{3}{*}{5.32} \\
\hline & & Sample-2 & 22.586 & 26.587 & 4.001 & 22.799 & 0.213 & 5.324 & \\
\hline & & Sample-3 & 23.738 & 27.745 & 4.007 & 23.938 & 0.200 & 4.991 & \\
\hline & \multirow{3}{*}{ 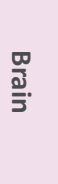 } & Sample-1 & 23.148 & 27.152 & 4.004 & 23.429 & 0.349 & 8.716 & \multirow{3}{*}{8.74} \\
\hline & & Sample-2 & 23.737 & 27.746 & 4.009 & 24.117 & 0.380 & 9.478 & \\
\hline & & Sample-3 & 25.250 & 29.255 & 4.005 & 25.571 & 0.321 & 8.014 & \\
\hline & \multirow{3}{*}{ 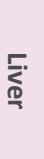 } & Sample-1 & 23.152 & 27.155 & 4.003 & 23.429 & 0.277 & 6.930 & \multirow{3}{*}{6.56} \\
\hline & & Sample-2 & 22.050 & 26.057 & 4.007 & 22.282 & 0.232 & 5.789 & \\
\hline & & Sample-3 & 23.805 & 27.807 & 4.002 & 24.084 & 0.279 & 6.971 & \\
\hline
\end{tabular}


TABLE 2: Comparison of mean fraction of ash values

\begin{tabular}{llll} 
& Chicken & Goat & Buffalo \\
\cline { 2 - 4 } Heart & $5.18 \%$ & $2.53 \%$ & $5.32 \%$ \\
Brain & $7.62 \%$ & $11.18 \%$ & $8.74 \%$ \\
Liver & $6.56 \%$ & $4.24 \%$ & $6.56 \%$ \\
\hline
\end{tabular}

respectively (Table 1). The comparison of the mean ash values of the three vital organs of the three different species is tabulated in Table 2.

\section{DISCUSSION}

The Unani philosophers and physicians have attributed specific Mizāj to each species, sex, stages of life, Akhlāț, organs, Arwāḥ, foods, medicines, seasons, places, and so on. Aristotle believed that the most Hārrr Rukn is fire, the most Bārid Rukn is water, the most Rațb Rukn is air, and the most Yäbis Rukn is earth in the world (9), and these Kayfiyāt cannot exist in a uniform ratio in any condition. Philosophers believed that the Kayfiyāt attributed to any matter are always relative to certain context and may vary in different contexts. Arkān are the only components where Kayfiyāt are absolute and fixed (10).

The dominance of a Kayfiyāt is due to the presence of its relevant Ajzā' Awwaliah (primary constituents). The presence of Harārat is believed to be due to Rukn Nār or Rukn Hawā', Burūdat is due to Rukn Mā' or Rukn Ard, Rutūbat is due to Rukn Hawā' or Rukn Mā', and Yubūsat is due to Rukn Arḍ or Rukn Nār. In other terms, if something among Mawālīd Thalatha is attributed to Haărr-Rațba, then it connotes the presence of Ajzā'Hawā'iyya in excess; likewise, if attributed to Hāârr-Yābis, then it signifies the presence of Ajzā' Nāriyya in surplus; if attributed to Bārid-Rațb, then it denotes the presence of Ajzā' Mā'iyya in excess; and if attributed to Bārid-Yābis, then it implies the dominance of Ajzā' Arḍiyya (3).

Therefore, the attribution of Mizāj is based on Kayfiyāt of Ajzā' Awwaliyyah. For instance, organs exhibit their Mizāj and properties as per their dominant Rukn and their respective Kayfiyāt. It is a physiological fact that all organs require certain affinity of Kayfiyāt that enables them to perform their functions.
A simple observation of organs reveals certain inherent Mizāj in them. The bones, for example, being stiff and hard are attributed to Bārid-Yābis, which enables them to support the weight of the body. The liver, with its reddish-brown color and warm and spongy texture, is attributed to Hārr-Rațb as it is intrinsically designed for producing Akhlāț. If organs were perfectly equal to their ratio of Kayfiyāt, then the body would have been inert and static. Thus, the Mizāj of organs is in congruence to their natural needs, and they influence the Mizāj of an individual as a whole (2-6).

The organs are most vulnerable to Kayfiyāt that run counter to those it needs for optimal functioning. For example, the brain is the Bārid-Rațb organ and its functions will seriously impair at times of high fever or excessive Harārat as well as dehydration in the body. Thus, the basic vulnerabilities of an organ tell a lot about its Mizāj-i-Asli. Deviations from Mizāj-i-Asli would compromise its Quwā and Ṭabīat, leaving organs vulnerable to dysfunction and disease $(2,3)$.

The philosophers have described the Mizāj of heart as Ḥārr-Yābis, of brain as Bārid-Rațb, and of liver as Haārr-Rațb. This attribution of Kayfiyāt indicates the presence of pertaining dominant Ajzā' Awwaliyya in the vital organs. In the heart, it is believed that Kayfiyāt Ḥārr may be because of Ajzā'Nāriyya or Ajzā'Hawā'iyya, and Kayfiyāt-i-Yābis may be due to Ajzā'Arḍiyya or Ajzā' Nāriyya. In the brain, Kayfiyāt Bārid may be due to Ajzā' Mā'iyya or Ajzā' Arḍiyya, and Kayfiyāt Rațb may be due to Ajzā' Hawā'iyya or Ajzā' Mā'iyya. In the liver, Kayfiyāt Hăārr may be due to Ajzā' Nāriyya or Ajzā'Hawā'iyya, and Kayfiyāt Rațb may be due to Ajzā' Hawā’iyya or Ajzā' Mā'iyya (3-5).

In this study, determining the cause of Yubūsat in the heart, using the ash value estimation was of prime concern. So, a comparative analysis of ash values of three vital organs, the heart, brain, and liver, of three different species, chicken, goat, and buffalo, was carried out.

The hypotheses formulated for testing were as follows:

$\mathrm{H}_{0}=$ No difference exists in ash values of the three vital organs in the three different species. 
$\mathrm{H}_{\mathrm{A} 1}=$ If the mean total ash value of the heart is higher than that of the brain and liver, it will connote the cause of Yubūsat as Yubūsat Arḍiyya.

$H_{A 2}=$ If the mean total ash value of the heart is lesser than that of the brain and liver, then Yubūsat will be implied as Yubūsat Nāriyya.

The mean total ash values of the brains were maximum among all the three species, chicken, goat, and buffalo (i.e., 7.62\%, $11.18 \%$, and $8.74 \%$, respectively; Table 2). The total ash values of the brains of the three species indicate the presence of Burūdat Arḍi, which could be the grounds of attribution of Kayfiyāt Bārid in the brain. Moreover, the Kayfiyāt Rațb of the brain may be because of Ajzā' Mā'iyya or Ajzā' Hawā'iyya, which are volatile and were not under study.

The mean total ash values of the livers in the three species, chicken, goat, and buffalo, were lesser than those of the brains and higher than those of the hearts (i.e., 6.56\%, 4.24\%, and $6.56 \%$, respectively; Table 2). This result indicates the presence of Ajzā' Ardiyya in lesser amount in the liver, for which the philosophers would have attributed its Mizāj as Hāārr-Rațb. The presence of Ajzā' Ardiyya in the liver validates the philosophy that each organ possesses all Arkān in varied ratios. Moreover, in the liver the presence of other Arkān, that is, Ajzā' Nāriyya, Ajzā'Hawā'iyya, and Ajzā'Mā’iyya, would be in higher quantity than Ajzā' Arḍiyya and so the Mizāj is attributed as Hâarr-Raṭb. It seems that the attribution to Harārat is due to the presence of Ajzā' Nāriyya or Ajzā' Hawā'iyya in excess, and Ruțūbat is due to the occurrence of Ajzā' Hawā'iyya or Ajzā' Mā'iyya in surplus.

The mean total ash values of the hearts in the three species, chicken, goat, and buffalo, were least compared with those of the brains and livers $(5.18 \%, 2.53 \%$, and $5.32 \%$, respectively; Table 2). This result indicates the presence of Ajzä' Ardiyya in least amount in the heart, and the attribution of Yubüsat in the heart is of Yubūsat Nāri. Moreover, Harārat is because of Ajzā' Nāriyya in dominance or the presence of Ajzā' Hawā'iyya in it.
Yubūsat is needed for hardness, stiffness, and durability to stay active and dynamic $(3,7)$. Compared with the brain and liver, the heart is more rigid in nature, which indicates the presence of Yubūsat in it. The heart's consistent activity and resemblance with the flame shape of Rukn Nār also signify the presence of Yubūsat Nāriyya.

Since the heart is a blend of volatile and non-volatile Ajzā' Awwaliyya, through combustion, the Ajzā' Lațîf (rarefied portion; i.e. Ajzā' Nāriyya, Ajzā' Hawā'iyya and Ajzā' Mā'iyya) disperses and the Ajzā’ Kathîf (dense portion; i.e., Ajzā' Arḍiyya) remains as ash.

In this study, the least total ash value of the heart among all the three species implies the least presence of Ajzā' Arḍiyya and, in turn, validates the presence of Yubüsat Nāriyya in it. Thus, the heart's shape, firmness and function are in accordance with its Harārat and Yubūsat Nāriyya.

\section{CONCLUSION}

Of these vital organs, philosophers' believed that only one organ was Bārid, that is, the brain. The Burūdat of the brain is not of such degree that it could modify the Harārat of the heart and liver. In this study, the highest mean ash value of the brain in all the three species suggests that the Burūdat in it is Burūdat Ardivya.

Philosophers also consider the other vital organ, heart, as Yâbis or nearly so. The Yubūsat in it is not up to such a level so as to alter the Ruțūbat of the brain and liver. The least mean ash value of the heart of all the three species validates its Yubüsat as Yubūsat Nāriyya.

However, neither the brain is absolutely Bārid nor the heart is entirely Yâbis. In fact, the heart in relation to the brain and liver is Yābis. Similarly, the brain in relation to the heart and liver is Bārid.

This study is unique of its kind, as no attempt has ever taken place in the past to quantify the Rukn. This analysis would provide a new window to understand the Mizāj of vital organs, determining their structure and functions. Therefore, it is hoped, 
this study not only will provide a sound basis for all future discussions on the heart's structure and function but will also help seek an explanation of the deeper intricacies of the basic principles of Unani medicine, as they are not self-evident to everyone.

\section{REFERENCES}

1. Rabban Tabarī Abu'l Hasan 'Ali ibn Sahl. Firdaws al-Hikma fi'l Tibb (Urdu Translation by Rasheed Ashraf Nadwi). New Delhi: CCRUM, Ministry of H\&FW; 2010:65-71,74-76,78,140,467.

2. Ibn Rushd. Kitāb al-Kulliyyāt (Urdu Translation by CCRUM). New Delhi: CCRUM, Ministry of H\&FW; 1987:32,34,35,49$52,112,147-150,153$.

3. Ibn Sīnā al-Shaykh al-Ra'îs Abu 'Alī al-Husayn ibn 'Abd Allāh. AlQānūn fi'l Tibb (Urdu Translation by Ghulām Ḥasnayn Kintūrī). Vol.1. New Delhi: Idāra Kitāb al-Shifa; 2010:17,21,24-26,28.

4. Jurjānī Sharaf al-Dīn Ismā'îl ibn Husayn. Dhakhīra Khawārizm Shāhī (Urdu Translation by Hādī Husayn Khān). Vol.1. New Delhi: Idāra Kitāb al-Shifā; 2010:12,13,15,17,20.
5. Majūsī 'Ali ibn 'Abbās. Kāmil al-Șanā'a al-Ṭibbiyya (Urdu Translation by Ghulām Ḥasnayn Kintūrī). Vol.1. New Delhi: Idāra Kitāb al-Shifā; 2010:21,23,31,32.

6. Jālīnūs. Kitāb fi'l Mizāj (Urdu Translation by Syed Zillur Rahman). Aligarh: Ibn Sīnā Academy; 2008:102,103,105,114,12-126.

7. Rāzī Abū Bakr Muhammad ibn Zakariyya. Kitāb al-Murshid (Urdu Translation by Razi ul Islam Nadwi). New Delhi: Taraqqi Urdu Bureau; 2000:27-32.

8. ISO 936:1998(E). Meat and meat products- Determination of total ash. Sec Edn. [Internet] cited on Feb 2, 2014. Available at http://www.eac-quality.net/fileadmin/eac_quality/ user_documents/3_pdf/CD-K-717-2010 Meat_and_ meat _products_-_Determination_of_total_ash.pdf

9. Stephen M Modell. Aristotelian influence in the formation of medical theory.

10. [Internet] cited on March 11, 2015. Available from https://helda. helsinki.fi/bit stream/handle/10138/15312/ 14_46_Modell. pdf? sequence $=1$

11. Ṭabarī Abu'l Hasan Ahmad ibn Muhammad. Mu'ālajāt alBaqrātīs al-Kunnāsh al-Ma'rūf bi'l Mu'ālajāt al-Buqrāțiyya (Urdu Translation by CCRUM). Vol.1\&3. New Delhi: CCRUM, Ministry of H\&FW; 1997:22,202. 